\title{
Can Getting Enough Vitamin D during Pregnancy Reduce the Risk of Getting Asthma in Childhood?
}

\author{
Evangelia Bountouvi, Konstantinos Douros and Anna Papadopoulou* \\ Third Department of Pediatrics, Athens University Medical School, University General Hospital "Attikon", Athens, Greece
}

The worldwide increase in asthma prevalence during the last decades and the re-emergence of vitamin $\mathrm{D}$ deficiency in many populations hinted toward an underlying association between these two conditions. Since asthma is presented with high incidence in childhood and neonatal vitamin D stores depend on maternal vitamin levels, a possible programming effect of maternal vitamin $D$ status during gestation was suggested. Observational and longitudinal studies on this subject led to inconclusive results with glimmer of positivity. In the randomized controlled clinical trials (RCTs) that followed, increased doses of vitamin $D$ were tested in pregnant women being at high risk of having an asthmatic child. Although, the results of RCTs showed a potential

OPEN ACCESS

Edited by:

Luis Garcia-Marcos,

University of Murcia, Spain

Reviewed by:

Yusei Ohshima,

University of Fukui, Japan

Giuseppe Pingitore,

Allergy Unit "G.B.Grassi”

Hospital, Italy

*Correspondence:

Anna Papadopoulou anpapado@med.uoa.gr

Specialty section: This article was submitted to Pediatric Pulmonology, a section of the journal

Frontiers in Pediatrics

Received: 31 January 2017 Accepted: 07 April 2017

Published: 26 April 2017

Citation:

Bountouvi E, Douros K and Papadopoulou A (2017) Can Getting

Enough Vitamin D

during Pregnancy Reduce the Risk of Getting Asthma in Childhood?

Front. Pediatr. 5:87.

doi: 10.3389/fped.2017.00087 association with asthma-related phenotypes rather than asthma per se, the low toxicity of vitamin D supplements make it tempting to speculate that pregnant women at a high risk of obtaining a child with asthma may be benefited, especially if they are vitamin $D$ deficient.

Keywords: vitamin D, asthma, childhood, pregnancy outcome, vitamin D supplementation

\section{INTRODUCTION}

Epidemiological and experimental data on health impact of "multitasking" vitamin D support a protective effect of vitamin D over diseases such as cancer, cardiovascular, autoimmune, dementia, and diabetes $(1,2)$. Recently, randomized clinical trials have been conducted to determine optimal serum concentrations and optimal intake of vitamin D that might be beneficial to human health (3-5). The prevention of asthma development is one of the many potential health benefits of vitamin $\mathrm{D}$ (6). Since asthma is presented with high incidence in childhood, a possible programming effect of maternal vitamin D status during gestation has been proposed. Besides, pregnant women and infants are in high risk of vitamin D insufficiency (7-11). Several observational studies explored this issue and suggested a putative protective role of prenatal vitamin D sufficiency in the development of wheezing and asthma in the offspring [reviewed in Ref. (12)]. However, it remains unclear whether maternal vitamin D deficiency may contribute to the development of childhood asthma or it is the consequence of a generally altered biochemistry. In this mini-review article, we aim to present the current knowledge as it emerges from studies focused on the impact of maternal vitamin D status and vitamin D supplementation on the development of asthma in early childhood.

\section{VITAMIN D LEVELS DURING PREGNANCY}

The main role of vitamin D during pregnancy is to maintain serum calcium levels by promoting calcium absorption in the intestine and allowing proper function of parathyroid hormone. 
It is, however, interesting that, during this period, vitamin D metabolism is shifted from the classical determinants of calcium homeostasis to other regulatory mechanisms. Although $25(\mathrm{OH})$ D circulating levels do not substantially differentiate or may be reduced compared to non-pregnant women, serum concentrations of vitamin $\mathrm{D}$ active metabolite, $1,25(\mathrm{OH})_{2} \mathrm{D}$, are significantly elevated from early pregnancy $(13,14)$. This increased production possibly depends on $25(\mathrm{OH}) \mathrm{D}$ substrate availability $(2,15)$. It should be noticed that high maternal intake of $25(\mathrm{OH})$ $\mathrm{D}$ or exceeding vitamin $\mathrm{D}$ serum levels during pregnancy is not complicated from either hypercalcemia or hypercalciuria (16). Moreover, $1,25(\mathrm{OH})_{2} \mathrm{D}$ synthesis by 1 - $\alpha$-hydroxylase (CYP27B1) may be triggered by other modifiers, which are increased during gestation, such as parathyroid hormone-related protein, prolactin, estradiol (17), calcitonin (18-20), and placental lactogen. Furthermore, an autocrine or paracrine placental function of upregulated CYP27B1 (21-24) and methylation of CYP24A1 gene, which induces lower levels of catabolic 24-hydroxylase, have also been suggested to contribute to the exceeding levels of $1,25(\mathrm{OH})_{2} \mathrm{D}$ in pregnancy. Circulated $25(\mathrm{OH}) \mathrm{D}$ concentration of $40 \mathrm{ng} / \mathrm{ml}$ (100 nmol/l), more likely to be achieved by 4,000 IU D3 daily intake, has been proposed as the cutoff level to optimize maternal $1,25(\mathrm{OH})_{2} \mathrm{D}$ levels (15).

$1,25(\mathrm{OH})_{2} \mathrm{D}$ does not pass through the hemochorial placenta, and fetal levels of $1,25(\mathrm{OH})_{2} \mathrm{D}$ are expected to be lower than the maternal (17). Cord blood levels of $25(\mathrm{OH}) \mathrm{D}$ correlate with $1,25(\mathrm{OH})_{2} \mathrm{D}$ whereas this is not the case for maternal circulation (25). Contrary to $1,25(\mathrm{OH})_{2} \mathrm{D}, 25(\mathrm{OH}) \mathrm{D}$ and its catabolic product, $24,25(\mathrm{OH})_{2} \mathrm{D}$, readily cross the placenta. Consequently, the infant basically depends on mother's $25(\mathrm{OH}) \mathrm{D}$ stores. Indeed, a strong correlation between maternal and cord blood $25(\mathrm{OH}) \mathrm{D}$ concentrations has been highlighted $(26,27)$. As a result, vitamin $\mathrm{D}$ deficiency during pregnancy exerts significant impact on vitamin D status of newborns and subsequently on early childhood $(9,28)$.

\section{THE IMPACT OF VITAMIN D EXPOSURE IN UTERO}

The dependence of the developing fetus on maternal vitamin $\mathrm{D}$ status together with the reported extra skeletal function of the hormone and vitamin $\mathrm{D}$ deficiency epidemic during the last years led to further investigation of the consequences of maternal vitamin D insufficiency on pregnancy outcomes $(6,29,30)$. Gestational vitamin D has now been linked to a variety of diseases such as osteoporosis, autoimmune disorders, altered brain development and adult mental health, food allergies, and asthma $(17,29,31-33)$. The most cited adverse outcome of maternal vitamin $\mathrm{D}$ deficiency is neonatal rickets, while mild hypovitaminosis $\mathrm{D}$ could be more pronounced in exclusively breast-fed infants, on the basis that breast milk constitutes a poor source of vitamin D compared with formulas (34-36). In the light of the possible parallel-asthma epidemic, cellular molecular studies along with epidemiological data suggest that vitamin D deficiency may have a programming effect in utero and promote a trajectory to develop asthma in childhood and later in life (2, 37-39).
An immunodulatory role of vitamin $\mathrm{D}$ has also been described in both immune system and lung cell maturation, which occurs mainly during fetal and early extrauterine life (40-42).

\section{MATERNAL VITAMIN D STATUS AND ASSOCIATIONS WITH ASTHMA IN EARLY LIFE}

The putative effect of prenatal exposure to vitamin D on asthmatic phenotypes in early life has been initially investigated via observational studies based on either maternal dietary intake of vitamin $\mathrm{D}$ or $25(\mathrm{OH}) \mathrm{D}$ levels in venous maternal and/or cord blood [reviewed in Ref. (12)]. Mainly, the food-approached studies have suggested a protective role of vitamin D intake on the development of wheezing and asthma in offspring, with an attenuated effect after adjustment for multiple covariables (43-48). Despite weak associations, meta-analyses and systemic reviews replicated the potential link, warranting further investigation (49-52). Consequently, longitudinal studies measuring $25(\mathrm{OH}) \mathrm{D}$ levels, a possible more objective indicator of vitamin D status, were designed to explore the possible impact of vitamin $\mathrm{D}$ on asthma-like symptoms or asthma. However, these derived data failed to consistently replicate this inverse connection. A spectrum of all possible associations has accrued, demonstrating no association (53-57), an inverse (58-61), a $U$-curved $(62,63)$, and even a direct relationship $(64,65)$ between the two entities. In accordance, systematic reviews and meta-analyses on these birth cohort studies reproduced inconclusive evidence, revealing no association with asthma or wheezing (66), a $U$-shaped association with a lower risk of childhood asthma at maternal $25(\mathrm{OH})$ D levels of $30 \mathrm{ng} / \mathrm{ml}$ (70 nmol/l) (67) and a borderline significant inverse relationship (68).

Inconsistencies across studies have been attributed to a plethora of factors such as diverse study designs, missing significant follow-up, lack of a clear definition of vitamin D sufficiency in pregnancy, remarkable fluctuations in populations in different latitudes, genetic heterogeneity, the diversity of assays employed (69), low repeatability of serum 25(OH)D values (37), variety of vitamin $\mathrm{D}$ status determinants, multifactorial nature and phenotypical diversity of asthma, as well as imprecision in diagnosing asthma in early life. Moreover, the majority of the cohorts assessed a single measurement of $25(\mathrm{OH}) \mathrm{D}$ in cord blood or late pregnancy, which might not sufficiently reflect the virtual vitamin status during gestational dynamic process. Of note, food base approaches may be assumed as a better representative of long-term vitamin $\mathrm{D}$ intake, which might influence the fetus during all stages of gestation and even ex utero.

The inconsistent body of evidence with glimmer of positivity from observational prospective cohorts, the rather low toxicity of vitamin $\mathrm{D}$, which is a relative inexpensive candidate in the attenuation of the asthma's epidemic burden on public health, were clearly indicative of the need to proceed to clinical trials. Moreover, both animal and in vitro experiments have demonstrated a positive impact of prenatal vitamin $\mathrm{D}$ exposure on aspects of lung function and the process of inflammation, which are considered to contribute to asthma pathogenesis (70-72). 
The first interventional study was conducted by Goldring et al. in UK (Table 1). The sample consisted of women with various ethnicities. Daily vitamin consumption of 800 IU D2 during the last trimester of pregnancy did not reveal any association with lung function, airway inflammation, and recurrent or asthmapredicting wheezing at 3 years of age, in comparison with the control group (73). In a recent randomized placebo-controlled double-blind trial in New Zealand, vitamin D was administrated in unselected pregnant women from the 27 weeks of gestation and subsequently in their infants during the first 6 months of life (placebo/placebo, 1,000/400 IU, and 2,000/800 IU). Despite that there was no difference preserved in the offspring's $25(\mathrm{OH})$ $\mathrm{D}$ level at the age of 18 months, a statistically significant lower proportion of children, belonged to vitamins D groups, were sensitized to mite antigens, as indicated by specific IgE measurements. Besides, a possible effect of vitamin D was depicted on primary care visits, where asthma was diagnosed by physicians (74). However, these clinical trials were biased by many limitations, such as small size, vitamin D administration only in the last trimester of pregnancy, possibly inadequate maternal dose administration, while authors also acknowledged that they were not primary designed to assess the specific outcome. Moreover, the first trial was not double blind and pertaining to the second one, a diagnosis of asthma at the age of 18 months was rather vague. Still, the association of vitamin D with asthma, ambiguously emerged from observational studies, could not be confirmed and established as a causative factor. Thus, further well-designed, randomized, controlled double blind trials followed to overcome the limitations of the previous studies and address the issue.

Recently, the results of two randomized controlled clinical trials (RCTs) were presented. In Denmark, Chawes et al. recruited 623 unselected women who were randomized to receive either 2,800 or 400 IU (as part of routine care) of vitamin D daily from 24 weeks of gestation until the first postpartum week. Adherence was assessed by returned pills and the follow-up rate was $94 \%$. The primary outcome was persistent wheezing in the offspring in the first 3 years of age. A no significant $4 \%$ absolute reduction in incidence of wheezing was reported in the children whose mothers were assigned to 2,800 IU group (hazard ratio, 0.76 [95\% CI 0.52-1.12]). Pertaining to secondary outcomes, the number of troublesome lung symptoms was significant lower in children of the intervention arm. However, no association was observed with asthma or other allergic diseases at 3 years of age (75). The second multicenter double-blind RCT was conducted in USA by Litonjua et al. Pregnant women on high risk to obtain children with asthma were randomized to either an interventional arm receiving 4,400 IU of vitamin $\mathrm{D}$ or to a control arm receiving $400 \mathrm{IU}$, as usual care, from 10 to 18 weeks of gestation until delivery. Compliance was measured by electronic medication containing caps. Ultimately, 748 children from the 876 initially enrolled mothers were followed up to 3 years of age. The cumulative incidence of asthma or wheezing was 6.1 lower in the intervention group in the first 3 years of life, but this was a borderline result, which did not meet statistical significance [hazard ratio, 0.8 (95\% CI 0.6-1.0)]. Moreover, this effect was reported to be attenuated with increasing age. Of note, despite the intervention significantly increased circulating vitamin D levels in women, 1-year postpartum no difference was preserved (76).

Although the results of both RCT did not meet statistical significance, the wide confidence intervals, which include a clinically important protective effect suggest that the studies may have been underpowered to measure the primary outcomes. A recent meta-analysis, which processed these data from both these two RCT and the study of Goldring et al., suggested that prenatal daily supplement of vitamin D might have a positive effect on childhood wheezing [relative risk, 0.812 (95\% CI 0.673-0.98)] (77). Given the fact that wheezing, usual viral-induced, in early childhood is a frequent cause of hospitalization and morbidity (78), further studies to confirm the possible causality are warranted.

Taken all together, vitamin D shows a potential association rather with asthma-related phenotypes than with asthma per se. For instance, in early childhood, wheezing is frequent transient or viral induced and $60 \%$ of these children are not expected to develop asthma (79). Therefore, it remains to be answered if a real cause-effect relationship exists or vitamin $\mathrm{D}$ exerts a protective role via other underlying mechanisms of this multifactorial disease, such as lung function or protection against viral infections. Additionally, vitamin D is a marker of UV exposure, which can modulate immunity via non-vitamin $\mathrm{D}$ related pathways $(80,81)$. Furthermore, as far as asthma diagnosis is ambiguous at the first 3 years of life, long-term follow-up may contribute to explore the possible relationship. However, the attenuation of the observed effect with aging $(59,74,76)$ complicates this theory. Notably, a large prospective observational birth cohort with longterm follow-up until early adulthood did not reveal a protective programming effect of high maternal $25(\mathrm{OH}) \mathrm{D}$ concentration in the third trimester of pregnancy on asthma at the age of 20 years, whereas maternal 25(OH)D levels over $50 \mathrm{ng} / \mathrm{ml}(125 \mathrm{nmol} / \mathrm{l})$ were associated with higher risk of asthma hospitalization during the first 25 years of life (65). Moreover, it has been proposed that studies should focus on vitamin D status in early pregnancy and supplementary administration should be initiated from the first trimester of gestation in order to observe the optimal effect on risk of childhood asthma, though evidence from Chawes et al.s clinical trial did not confirm this notion (75). In addition, an interesting remark is that study designs and analyses do not take into consideration the starting maternal vitamin $\mathrm{D}$ status and dose adequacy for the different body systems. This is also an issue that should be addressed.

Irrefutably, both entities of asthma and vitamin D deficiency are multifactorial. A plethora of environmental and genetic/ epigenetic factors contribute in a complex manner to a partly understood pathogenesis, while the shifted vitamin D metabolism during pregnancy is also not fully elucidated. As a result, unmeasured aspects and residual confounding factors are rather difficult to be diminished from the studies. Besides, even if the putative effect suggested by the current RCTs be strengthened by further investigations, this would only explain a little proportion of asthma epidemic. Shifting the discussion to a clinical platform, vitamin $\mathrm{D}$ administration during pregnancy has not yet been justified. However, given the rather low toxicity of such a supplement and based on the evidence derived of the two RCTs, pregnant women at a high risk of obtaining a child with asthma may be 
TABLE 1 | Randomized control trials on vitamin D supplementation during pregnancy and asthma/wheezing.

\begin{tabular}{|c|c|c|c|c|c|c|c|c|}
\hline Reference & $\begin{array}{l}\text { Country } \\
\text { and } \\
\text { enrollment } \\
\text { period }\end{array}$ & $\begin{array}{l}\text { Study } \\
\text { population }\end{array}$ & $\begin{array}{l}\text { Intervention } \\
\text { arms }\end{array}$ & $\begin{array}{l}\text { Number/age } \\
\text { of children } \\
\text { at outcome } \\
\text { assessment }\end{array}$ & $\begin{array}{l}\text { Intake of } \\
\text { intervention } \\
\text { from/until }\end{array}$ & $\begin{array}{l}\text { Effect on median } \\
\text { vitamin } D \text { levels }(\mathrm{ng} / \mathrm{ml})\end{array}$ & $\begin{array}{l}\text { Outcomes of } \\
\text { interest }\end{array}$ & Main findings \\
\hline \multirow{4}{*}{$\begin{array}{l}\text { Goldring } \\
\text { et al. (73) }\end{array}$} & \multirow[t]{4}{*}{ UK 2007} & \multirow{4}{*}{$\begin{array}{l}180 \text { mother- } \\
\text { child pairs } \\
4 \text { Ethnic } \\
\text { groups: } \\
\text { Asian, Middle } \\
\text { Eastern, } \\
\text { Black and } \\
\text { White }\end{array}$} & Not blinded & \multirow[t]{4}{*}{$158 / 3$ years } & \multirow{4}{*}{$\begin{array}{l}\text { Mothers: } \\
27 \text { weeks of } \\
\text { gestation to } \\
\text { delivery }\end{array}$} & \multirow{4}{*}{$\begin{array}{l}\text { Higher in cord blood of supplementary } \\
\text { arm (control } 6.8 \text {, daily dose } 10.4 \text {, single } \\
\text { dose } 10 p<0.001 \text { ) }\end{array}$} & \multirow{4}{*}{$\begin{array}{l}\text { Blinded } \\
\text { Wheezing, eczema, } \\
\text { food allergy, } \\
\text { rhinitis, atopy, } \\
\text { URTI, LRTI, inhaled } \\
\text { bronchodilator or } \\
\text { steroids }\end{array}$} & \multirow{2}{*}{$\begin{array}{l}\text { No significant difference between } \\
\text { groups in risk of wheezing at } 3 \text { years } \\
\text { of age (RR: } 0.86,95 \% \mathrm{Cl} 0.49-1.50 p=0.69 \text { ) }\end{array}$} \\
\hline & & & $\begin{array}{l}\text { Women: no } \\
\text { treatment }(N=60)\end{array}$ & & & & & \\
\hline & & & $\begin{array}{l}800 \mathrm{IU}(N=60) \\
\text { ergocalciferol daily }\end{array}$ & & & & & $\begin{array}{l}\text { No significant difference between groups } \\
\text { pertaining to rest secondary outcomes }\end{array}$ \\
\hline & & & $\begin{array}{l}200,000 \text { IU } \\
(N=60) \\
\text { cholecalciferol } \\
\text { single bolus oral } \\
\text { dose }\end{array}$ & & & & & \\
\hline \multirow{6}{*}{$\begin{array}{l}\text { Grant } \\
\text { et al. (74) }\end{array}$} & \multirow{6}{*}{$\begin{array}{l}\text { New } \\
\text { Zealand } \\
\text { 2010-2011 }\end{array}$} & \multirow{6}{*}{$\begin{array}{l}260 \text { mother- } \\
\text { child pairs }\end{array}$} & Double-blinded & \multirow[t]{6}{*}{$185 / 18$ months } & \multirow{6}{*}{$\begin{array}{l}\text { Mothers: } \\
27 \text { weeks of } \\
\text { gestation to } \\
\text { delivery } \\
\text { Off springs: } \\
\text { birth to } \\
6 \text { months }\end{array}$} & Enrollment: $25 \rightarrow$ no difference $(p=0.19)$ & Secondary outcomes & \multirow{6}{*}{$\begin{array}{l}\text { Decreased proportion of children } \\
\text { sensitized to four mites antigens } \\
\text { Study group differences in the } \\
\text { proportion of children with primary care visits } \\
\text { of doctor-diagnosed asthma } \\
(11,0 \text {, and } 4 \%, p=0.002)\end{array}$} \\
\hline & & & \multirow{2}{*}{$\begin{array}{l}\text { Women/infant: } \\
\text { placebo/placebo }\end{array}$} & & & Cord blood: 27 vs $15 \rightarrow$ higher in both & \multirow{5}{*}{$\begin{array}{l}\text { Sensitization to } \\
\text { airborne allergens } \\
\text { Primary health care } \\
\text { visits for respiratory } \\
\text { illnesses }\end{array}$} & \\
\hline & & & & & & supplemented groups than in placebo & & \\
\hline & & & $1,000 / 400 \mathrm{IU}$ & & & $\begin{array}{l}6 \text { months of age: } 40 \text { vs } 30 \rightarrow \text { higher vit } D \\
\text { group had the highest and placebo group }\end{array}$ & & \\
\hline & & & $2,000 / 800 \mathrm{IU}$ & & & the lowest concentrations & & \\
\hline & & & & & & $\begin{array}{l}18 \text { months of age: } 24.4 \rightarrow \text { no difference } \\
(p=0.30)\end{array}$ & & \\
\hline \multirow{5}{*}{$\begin{array}{l}\text { Chawes } \\
\text { et al. (75) }\end{array}$} & \multirow{5}{*}{$\begin{array}{l}\text { Denmark } \\
\text { 2009-2010 }\end{array}$} & \multirow{5}{*}{$\begin{array}{l}623 \text { mother- } \\
\text { child pairs } \\
\text { recruited from } \\
\text { COPSAC }_{2010} \\
\text { cohort study }\end{array}$} & Double-blinded & \multirow[t]{5}{*}{$581 / 3$ years } & \multirow{5}{*}{$\begin{array}{l}\text { Mothers: } \\
24 \text { weeks of } \\
\text { gestation to } \\
1 \text { week after } \\
\text { delivery }\end{array}$} & Increase in maternal serum vitD level & \multirow{5}{*}{$\begin{array}{l}\text { Persistent wheeze, } \\
\text { asthma, URTI, LRTI, } \\
\text { episodes of lung } \\
\text { symptoms, SPT, } \\
\text { specific lgE }\end{array}$} & \multirow{2}{*}{$\begin{array}{l}\text { No significant reduction in the risk of } \\
\text { persistent wheezing per } 4 \mathrm{ng} / \mathrm{ml} \text { increase } \\
\text { in maternal serum vitamin D level } \\
\text { (HR: } 0.86,95 \% \mathrm{Cl} 0.89-0.99 p=0.03 \text { ) }\end{array}$} \\
\hline & & & $\begin{array}{l}\text { Placebo }+400 \mathrm{IU} \\
(N=308)\end{array}$ & & & $\begin{array}{l}\text { in treatment group (mean SD at } \\
\text { randomization vs postpartum: } 31 \text { vs } 43 \text {; } \\
\text { control group } 31 \text { vs 29) }\end{array}$ & & \\
\hline & & & \multirow[t]{3}{*}{$\begin{array}{l}\text { Cholecalciferol } \\
2,400+400 \mathrm{IU} \\
(N=315)\end{array}$} & & & $\begin{array}{l}\text { Mean group difference } 13 \text { [95\% Cl 11-16, } \\
p<0.001]\end{array}$ & & $\begin{array}{l}\text { Reduced number of troublesome lung } \\
\text { episodes (IRR: } 0.83,95 \% \mathrm{Cl} 0.71-0.97 \\
p=0.02 \text { ) }\end{array}$ \\
\hline & & & & & & & & $\begin{array}{l}\text { Upregulation or airway immune } \\
\text { profile (principal component analysis } \\
p=0.04 \text { ) }\end{array}$ \\
\hline & & & & & & & & No effect on additional end points \\
\hline \multirow{4}{*}{$\begin{array}{l}\text { Litonjua } \\
\text { et al. (76) } \\
\text { (VDAART) }\end{array}$} & \multirow{4}{*}{$\begin{array}{l}\text { USA } \\
\text { 2009-2011 }\end{array}$} & \multirow{4}{*}{$\begin{array}{l}876 \text { mothers } \\
\text { at high risk of } \\
\text { having child } \\
\text { with asthma }\end{array}$} & Double-blinded & \multirow[t]{4}{*}{$748 / 3$ years } & \multirow{4}{*}{$\begin{array}{l}\text { Mothers: } \\
\text { between } 10 \\
\text { and } 18 \text { weeks } \\
\text { of gestation to } \\
\text { delivery }\end{array}$} & Third trimester: higher in supplemented & \multirow{4}{*}{$\begin{array}{l}\text { Wheezing or asthma, } \\
\text { eczema with rash, } \\
\text { LRTI, mean total } \\
\text { lgE. Aeroallergens } \\
\text { sensitization, } \\
\text { specific lgE }\end{array}$} & \multirow{4}{*}{$\begin{array}{l}\text { No significant reduction in the incidence } \\
\text { of asthma and recurrent wheezing } \\
\text { by } 6.1 \% \text { (HR: } 0.8,95 \% \mathrm{Cl} 0.6-1.0 \\
p=0.51 \text { ) }\end{array}$} \\
\hline & & & $\begin{array}{l}\text { Placebo }+400 \mathrm{IU} \\
(N=436)\end{array}$ & & & $\begin{array}{l}\text { group vs control (39.2 vs 26.8, mean } \\
\text { difference 12.4; } 95 \% \mathrm{Cl} 10.5-14.3 \text {, } \\
p<0.001 \text { ) }\end{array}$ & & \\
\hline & & & \multirow[t]{2}{*}{$\begin{array}{l}4,000+400 \mathrm{IU} \\
(N=440)\end{array}$} & & & $\begin{array}{l}\text { Cord blood: significant difference } \\
\text { preserved }\end{array}$ & & \\
\hline & & & & & & 1 and 3 years postpartum: no difference & & \\
\hline
\end{tabular}


benefited, particularly if they are deficient (82). Moreover, any intervention should be individualized to initial maternal vitamin $\mathrm{D}$ status and be followed up, since a $U$-curve association between vitamin $\mathrm{D}$ circulating levels and impact on allergy and human health has been also proposed $(83,84)$.

\section{KEY ELEMENTS}

- Vitamin D shows a potential association rather with asthma-related phenotypes than with asthma per se. Further well-designed RCTs to confirm the possible associations are warranted.

- Vitamin D supplementation during pregnancy has not yet been justified. However, given the rather low toxicity

\section{REFERENCES}

1. Rosen CJ, Adams JS, Bikle DD, Black DM, Demay MB, Manson JE, et al. The nonskeletal effects of vitamin D: an endocrine society scientific statement. Endocr Rev (2012) 33(3):456-92. doi:10.1210/er.2012-1000

2. Pludowski P, Holick MF, Pilz S, Wagner CL, Hollis BW, Grant WB, et al. Vitamin D effects on musculoskeletal health, immunity, autoimmunity, cardiovascular disease, cancer, fertility, pregnancy, dementia and mortality - a review of recent evidence. Autoimmun Rev (2013) 12(10):976-89. doi:10.1016/ j.autrev.2013.02.004

3. Hollis BW, Wagner CL. Vitamin D requirements during lactation: highdose maternal supplementation as therapy to prevent hypovitaminosis D for both the mother and the nursing infant. Am J Clin Nutr (2004) 80 (6 Suppl):1752S-8S.

4. Autier P, Boniol M, Pizot C, Mullie P. Vitamin D status and ill health: a systematic review. Lancet Diabetes Endocrinol (2014) 2(1):76-89. doi:10.1016/ S2213-8587(13)70165-7

5. Bolland MJ, Grey A, Gamble GD, Reid IR. The effect of vitamin D supplementation on skeletal, vascular, or cancer outcomes: a trial sequential meta-analysis. Lancet Diabetes Endocrinol (2014) 2(4):307-20. doi:10.1016/ S2213-8587(13)70212-2

6. Bozzetto S, Carraro S, Giordano G, Boner A, Baraldi E. Asthma, allergy and respiratory infections: the vitamin D hypothesis. Allergy (2012) 67(1):10-7. doi:10.1111/j.1398-9995.2011.02711.x

7. Johnson DD, Wagner CL, Hulsey TC, McNeil RB, Ebeling M, Hollis BW. Vitamin D deficiency and insufficiency is common during pregnancy. Am J Perinatol (2011) 28(1):7-12. doi:10.1055/s-0030-1262505

8. Wahl DA, Cooper C, Ebeling PR, Eggersdorfer M, Hilger J, Hoffmann K, et al. A global representation of vitamin D status in healthy populations. Arch Osteoporos (2012) 7(1-2):155-72. doi:10.1007/s11657-012-0093-0

9. Nicolaidou P, Hatzistamatiou Z, Papadopoulou A, Kaleyias J, Floropoulou E, Lagona E, et al. Low vitamin D status in mother-newborn pairs in Greece. Calcif Tissue Int (2006) 78(6):337-42. doi:10.1007/s00223-006-0007-5

10. Hilger J, Friedel A, Herr R, Rausch T, Roos F, Wahl DA, et al. A systematic review of vitamin D status in populations worldwide. Br J Nutr (2014) 111(1):23-45. doi:10.1017/S0007114513001840

11. Hamilton SA, McNeil R, Hollis BW, Davis DJ, Winkler J, Cook C, et al. Profound vitamin $\mathrm{D}$ deficiency in a diverse group of women during pregnancy living in a sun-rich environment at latitude 32 degrees N. Int J Endocrinol (2010) 2010:917428. doi:10.1155/2010/917428

12. Papadopoulou A, Bountouvi E, Papaevaggelou V, Priftis KN. Maternal vitamin D status and development of asthma and allergy in early childhood. Mini Rev Med Chem (2015) 15(11):900-12. doi:10.2174/1389557515666150 519105741

13. Kovacs CS. Vitamin D in pregnancy and lactation: maternal, fetal, and neonatal outcomes from human and animal studies. Am J Clin Nutr (2008) 88(2):520S-8S. doi:10.1146/annurev-nutr-071811-150742

14. Wagner CL, Taylor SN, Johnson DD, Hollis BW. The role of vitamin D in pregnancy and lactation: emerging concepts. Womens Health (Lond) (2012) 8(3):323-40. doi:10.2217/whe.12.17 of such a supplement, pregnant women at a high risk of obtaining a child with asthma may be benefited, especially if they are vitamin $\mathrm{D}$ deficient. Any intervention should be individualized to initial maternal vitamin $\mathrm{D}$ status and be followed up.

\section{AUTHOR CONTRIBUTIONS}

AP contributed to the conception of the work, the revision, and the final approval of the manuscript. EB contributed to the design of the work, the drafting, and the final approval of text manuscript. KD contributed to the design of the work, the revision, and the final approval of the manuscript. All the authors agreed to be accountable for all aspects of the work.

15. Hollis BW, Johnson D, Hulsey TC, Ebeling M, Wagner CL. Vitamin D supplementation during pregnancy: double-blind, randomized clinical trial of safety and effectiveness. J Bone Miner Res (2011) 26(10):2341-57. doi:10.1002/ jbmr.463

16. Wagner CL, McNeil RB, Johnson DD, Hulsey TC, Ebeling M, Robinson C, et al. Health characteristics and outcomes of two randomized vitamin D supplementation trials during pregnancy: a combined analysis. J Steroid Biochem Mol Biol (2013) 136:313-20. doi:10.1016/j.jsbmb.2013.01.002

17. Liu NQ, Hewison M. Vitamin D, the placenta and pregnancy. Arch Biochem Biophys (2012) 523(1):37-47. doi:10.1016/j.abb.2011.11.018

18. Stevenson JC, Hillyard CJ, MacIntyre I, Cooper H, Whitehead MI. A physiological role for calcitonin: protection of the maternal skeleton. Lancet (1979) 2(8146):769-70. doi:10.1016/S0140-6736(79)92117-2

19. Shinki T, Ueno Y, DeLuca HF, Suda T. Calcitonin is a major regulator for the expression of renal 25-hydroxyvitamin D3-1alpha-hydroxylase gene in normocalcemic rats. Proc Natl Acad Sci U S A (1999) 96(14):8253-8. doi:10.1073/ pnas.96.14.8253

20. Zaidi M, Moonga BS, Abe E. Calcitonin and bone formation: a knockout full of surprises. J Clin Invest (2002) 110(12):1769-71. doi:10.1172/JCI17425

21. Ross R, Florer J, Halbert K, McIntyre L. Characterization of 1,25-dihydroxyvitamin D3 receptors and in vivo targeting of [3H]-1,25(OH)2D3 in the sheep placenta. Placenta (1989) 10(6):553-67. doi:10.1016/0143-4004(89)90047-7

22. Evans KN, Bulmer JN, Kilby MD, Hewison M. Vitamin D and placentaldecidual function. J Soc Gynecol Investig (2004) 11(5):263-71. doi:10.1016/ j.jsgi.2004.02.002

23. Delvin EE, Gagnon L, Arabian A, Gibb W. Influence of calcitriol on prolactin and prostaglandin production by human decidua. Mol Cell Endocrinol (1990) 71(3):177-83. doi:10.1016/0303-7207(90)90023-2

24. Zehnder D, Evans KN, Kilby MD, Bulmer JN, Innes BA, Stewart PM, et al. The ontogeny of 25-hydroxyvitamin $\mathrm{D}(3)$ 1alpha-hydroxylase expression in human placenta and decidua. Am J Pathol (2002) 161(1):105-14. doi:10.1016/ S0002-9440(10)64162-4

25. Walker VP, Zhang X, Rastegar I, Liu PT, Hollis BW, Adams JS, et al. Cord blood vitamin D status impacts innate immune responses. J Clin Endocrinol Metab (2011) 96(6):1835-43. doi:10.1210/jc.2010-1559

26. Salle BL, Delvin EE, Lapillonne A, Bishop NJ, Glorieux FH. Perinatal metabolism of vitamin D. Am J Clin Nutr (2000) 71(5 Suppl):1317S-24S.

27. Vieth Streym S, Kristine Moller U, Rejnmark L, Heickendorff L, Mosekilde L, Vestergaard P. Maternal and infant vitamin D status during the first 9 months of infant life - a cohort study. Eur J Clin Nutr (2013) 67(10):1022-8. doi:10.1038/ejcn.2013.152

28. Thomson K, Morley R, Grover SR, Zacharin MR. Postnatal evaluation of vitamin D and bone health in women who were vitamin D-deficient in pregnancy, and in their infants. Med J Aust (2004) 181(9):486-8.

29. Erkkola M, Nwaru BI, Viljakainen HT. Maternal vitamin D during pregnancy and its relation to immune-mediated diseases in the offspring. Vitam Horm (2011) 86:239-60. doi:10.1016/B978-0-12-386960-9.00010-1

30. Weiss ST, Litonjua AA. The in utero effects of maternal vitamin D deficiency: how it results in asthma and other chronic diseases. Am J Respir Crit Care Med (2011) 183(10):1286-7. doi:10.1164/rccm.201101-0160ED 
31. Hollis BW, Wagner CL. Vitamin D and pregnancy: skeletal effects, nonskeletal effects, and birth outcomes. Calcif Tissue Int (2013) 92(2):128-39. doi:10.1007/ s00223-012-9607-4

32. Dror DK, Allen LH. Vitamin D inadequacy in pregnancy: biology, outcomes, and interventions. Nutr Rev (2010) 68(8):465-77. doi:10.1111/j.1753-4887. 2010.00306.x

33. Weiss ST, Litonjua AA. Childhood asthma is a fat-soluble vitamin deficiency disease. Clin Exp Allergy (2008) 38(3):385-7. doi:10.1111/j.1365-2222.2007. 02920.x

34. Challa A, Ntourntoufi A, Cholevas V, Bitsori M, Galanakis E, Andronikou S. Breastfeeding and vitamin D status in Greece during the first 6 months of life. Eur J Pediatr (2005) 164(12):724-9. doi:10.1007/s00431-005-1757-1

35. Anatoliotaki M, Tsilimigaki A, Tsekoura T, Schinaki A, Stefanaki S, Nicolaidou P. Congenital rickets due to maternal vitamin D deficiency in a sunny island of Greece. Acta Paediatr (2003) 92(3):389-91. doi:10.1111/j. 1651-2227.2003.tb00563.x

36. Dawodu A, Agarwal M, Hossain M, Kochiyil J, Zayed R. Hypovitaminosis D and vitamin D deficiency in exclusively breast-feeding infants and their mothers in summer: a justification for vitamin D supplementation of breast-feeding infants. J Pediatr (2003) 142(2):169-73. doi:10.1067/mpd.2003.63

37. Lasky-Su J, Lange N, Brehm JM, Damask A, Soto-Quiros M, Avila L, et al. Genome-wide association analysis of circulating vitamin D levels in children with asthma. Hum Genet (2012) 131(9):1495-505. doi:10.1007/ s00439-012-1185-z

38. Litonjua AA. Vitamin D deficiency as a risk factor for childhood allergic disease and asthma. Curr Opin Allergy Clin Immunol (2012) 12(2):179-85. doi:10.1097/ACI.0b013e3283507927

39. Mirzakhani H, Al-Garawi A, Weiss ST, Litonjua AA. Vitamin D and the development of allergic disease: how important is it? Clin Exp Allergy (2014) 45:114-25. doi:10.1111/cea.12430

40. Barker DJ, Eriksson JG, Forsen T, Osmond C. Fetal origins of adult disease: strength of effects and biological basis. Int J Epidemiol (2002) 31(6):1235-9. doi:10.1093/ije/31.6.1235

41. Henderson AJ, Warner JO. Fetal origins of asthma. Semin Fetal Neonatal Med (2012) 17(2):82-91. doi:10.1016/j.siny.2012.01.006

42. Duijts L. Fetal and infant origins of asthma. Eur J Epidemiol (2012) 27(1):5-14. doi:10.1007/s10654-012-9657-y

43. Devereux G, Litonjua AA, Turner SW, Craig LC, McNeill G, Martindale S, et al. Maternal vitamin D intake during pregnancy and early childhood wheezing. Am J Clin Nutr (2007) 85(3):853-9.

44. Camargo CA Jr, Rifas-Shiman SL, Litonjua AA, Rich-Edwards JW, Weiss ST, Gold DR, et al. Maternal intake of vitamin D during pregnancy and risk of recurrent wheeze in children at $3 \mathrm{y}$ of age. Am J Clin Nutr (2007) 85(3):788-95.

45. Erkkola M, Kaila M, Nwaru BI, Kronberg-Kippila C, Ahonen S, Nevalainen J, et al. Maternal vitamin D intake during pregnancy is inversely associated with asthma and allergic rhinitis in 5-year-old children. Clin Exp Allergy (2009) 39(6):875-82. doi:10.1111/j.1365-2222.2009.03234.x

46. Miyake Y, Tanaka K, Okubo H, Sasaki S, Arakawa M. Maternal consumption of dairy products, calcium, and vitamin D during pregnancy and infantile allergic disorders. Ann Allergy Asthma Immunol (2014) 113(1):82-7. doi:10.1016/j.anai.2014.04.023

47. Miyake Y, Sasaki S, Tanaka K, Hirota Y. Dairy food, calcium and vitamin D intake in pregnancy, and wheeze and eczema in infants. Eur Respir $J$ (2010) 35(6):1228-34. doi:10.1183/09031936.00100609

48. Maslova E, Hansen S, Jensen CB, Thorne-Lyman AL, Strom M, Olsen SF. Vitamin D intake in mid-pregnancy and child allergic disease - a prospective study in 44,825 Danish mother-child pairs. BMC Pregnancy Childbirth (2013) 13:199. doi:10.1186/1471-2393-13-199

49. Netting MJ, Middleton PF, Makrides M. Does maternal diet during pregnancy and lactation affect outcomes in offspring? A systematic review of food-based approaches. Nutrition (2014) 30(11-12):1225-41. doi:10.1016/ j.nut.2014.02.015

50. Nurmatov U, Devereux G, Sheikh A. Nutrients and foods for the primary prevention of asthma and allergy: systematic review and meta-analysis. J Allergy Clin Immunol (2011) 127(3):e1-30. doi:10.1016/j.jaci.2010.11.001

51. Allan K, Devereux G. Diet and asthma: nutrition implications from prevention to treatment. J Am Diet Assoc (2011) 111(2):258-68. doi:10.1016/ j.jada.2010.10.048
52. Beckhaus AA, Garcia-Marcos L, Forno E, Pacheco-Gonzalez RM, Celedon JC, Castro-Rodriguez JA. Maternal nutrition during pregnancy and risk of asthma, wheeze, and atopic diseases during childhood: a systematic review and meta-analysis. Allergy (2015) 70(12):1588-604. doi:10.1111/all.12729

53. Pike KC, Inskip HM, Robinson S, Lucas JS, Cooper C, Harvey NC, et al. Maternal late-pregnancy serum 25-hydroxyvitamin D in relation to childhood wheeze and atopic outcomes. Thorax (2012) 67(11):950-6. doi:10.1136/ thoraxjnl-2012-201888

54. Morales E, Romieu I, Guerra S, Ballester F, Rebagliato M, Vioque J, et al. Maternal vitamin D status in pregnancy and risk of lower respiratory tract infections, wheezing, and asthma in offspring. Epidemiology (2012) 23(1):64-71. doi:10.1097/EDE.0b013e31823a44d3

55. Magnus MC, Stene LC, Haberg SE, Nafstad P, Stigum H, London SJ, et al. Prospective study of maternal mid-pregnancy 25-hydroxyvitamin D level and early childhood respiratory disorders. Paediatr Perinat Epidemiol (2013) 27(6):532-41. doi:10.1111/ppe.12080

56. Wills AK, Shaheen SO, Granell R, Henderson AJ, Fraser WD, Lawlor DA. Maternal 25-hydroxyvitamin D and its association with childhood atopic outcomes and lung function. Clin Exp Allergy (2013) 43(10):1180-8. doi:10.1111/ cea. 12172

57. Gazibara T, den Dekker HT, de Jongste JC, McGrath JJ, Eyles DW, Burne TH, et al. Associations of maternal and fetal 25-hydroxyvitamin D levels with childhood lung function and asthma: the Generation R Study. Clin Exp Allergy (2016) 46(2):337-46. doi:10.1111/cea.12645

58. Camargo CA Jr, Ingham T, Wickens K, Thadhani R, Silvers KM, Epton MJ, et al. Cord-blood 25-hydroxyvitamin D levels and risk of respiratory infection, wheezing, and asthma. Pediatrics (2011) 127(1):e180-7. doi:10.1542/ peds.2010-0442

59. Zosky GR, Hart PH, Whitehouse AJ, Kusel MM, Ang W, Foong RE, et al. Vitamin D deficiency at 16 to 20 weeks' gestation is associated with impaired lung function and asthma at 6 years of age. Ann Am Thorac Soc (2014) 11(4):571-7. doi:10.1513/AnnalsATS.201312-423OC

60. Baïz N, Dargent-Molina P, Wark JD, Souberbielle JC, Annesi-Maesano I. Cord serum 25-hydroxyvitamin D and risk of early childhood transient wheezing and atopic dermatitis. J Allergy Clin Immunol (2014) 133(1):147-53. doi:10.1016/j.jaci.2013.05.017

61. Stelmach I, Majak P, Jerzynska J, Podlecka D, Stelmach W, Polanska K, et al. Cord serum 25-hydroxyvitamin D correlates with early childhood viral-induced wheezing. Respir Med (2015) 109(1):38-43. doi:10.1016/ j.rmed.2014.10.016

62. Rothers J, Wright AL, Stern DA, Halonen M, Camargo CA Jr. Cord blood 25-hydroxyvitamin $\mathrm{D}$ levels are associated with aeroallergen sensitization in children from Tucson, Arizona. J Allergy Clin Immunol (2011) 128(5):e1-5. doi:10.1016/j.jaci.2011.07.015

63. Maslova E, Hansen S, Thorne-Lyman AL, Jensen CB, Strom M, Cohen A, et al. Predicted vitamin D status in mid-pregnancy and child allergic disease. Pediatr Allergy Immunol (2014) 25:706-13. doi:10.1111/pai.12295

64. Gale CR, Robinson SM, Harvey NC, Javaid MK, Jiang B, Martyn CN, et al. Maternal vitamin D status during pregnancy and child outcomes. Eur J Clin Nutr (2008) 62(1):68-77. doi:10.1038/sj.ejcn.1602680

65. Hansen S, Maslova E, Strom M, Linneberg A, Halldorsson TI, Granstrom C, et al. The long-term programming effect of maternal 25-hydroxyvitamin D in pregnancy on allergic airway disease and lung function in offspring after 20 to 25 years of follow-up. J Allergy Clin Immunol (2015) 136(1):169-176 e2. doi:10.1016/j.jaci.2014.12.1924

66. Wei Z, Zhang J, Yu X. Maternal vitamin D status and childhood asthma, wheeze, and eczema: a systematic review and meta-analysis. Pediatr Allergy Immunol (2016) 27(6):612-9. doi:10.1111/pai.12593

67. Song H, Yang L, Jia C. Maternal vitamin D status during pregnancy and risk of childhood asthmaa meta-analysis of prospective studies. Mol Nutr Food Res (2016). doi:10.1002/mnfr.201600657

68. Feng H, Xun P, Pike K, Wills AK, Chawes BL, Bisgaard H, et al. In utero exposure to 25-hydroxyvitamin D and risk of childhood asthma, wheeze, and respiratory tract infections: a meta-analysis of birth cohort studies. J Allergy Clin Immunol (2016). doi:10.1016/j.jaci.2016.06.065

69. Sempos CT, Vesper HW, Phinney KW, Thienpont LM, Coates PM. Vitamin D status as an international issue: national surveys and the problem of standardization. Scand J Clin Lab Invest Suppl (2012) 243:32-40. doi:10.3109/ 00365513.2012.681935 
70. Vasiliou JE, Lui S, Walker SA, Chohan V, Xystrakis E, Bush A, et al. Vitamin D deficiency induces Th2 skewing and eosinophilia in neonatal allergic airways disease. Allergy (2014) 69(10):1380-9. doi:10.1111/all.12465

71. Zosky GR, Berry LJ, Elliot JG, James AL, Gorman S, Hart PH. Vitamin D deficiency causes deficits in lung function and alters lung structure. Am J Respir Crit Care Med (2011) 183(10):1336-43. doi:10.1164/rccm.201010-1596OC

72. Black PN, Scragg R. Relationship between serum 25 -hydroxyvitamin d and pulmonary function in the third national health and nutrition examination survey. Chest (2005) 128(6):3792-8. doi:10.1378/chest.128.6.3792

73. Goldring ST, Griffiths CJ, Martineau AR, Robinson S, Yu C, Poulton S, et al. Prenatal vitamin D supplementation and child respiratory health: a randomised controlled trial.PLoS One (2013) 8(6):e66627. doi:10.1371/journal.pone.0066627

74. Grant CC, Crane J, Mitchell EA, Sinclair J, Stewart A, Milne T, et al. Vitamin D supplementation during pregnancy and infancy reduces aeroallergen sensitization: a randomized controlled trial. Allergy (2016) 71(9):1325-34. doi:10.1111/ all.12909

75. Chawes BL, Bonnelykke K, Stokholm J, Vissing NH, Bjarnadottir E, Schoos AM, et al. Effect of vitamin D3 supplementation during pregnancy on risk of persistent wheeze in the offspring: a randomized clinical trial. JAMA (2016) 315(4):353-61. doi:10.1001/jama.2015.18318

76. Litonjua AA, Carey VJ, Laranjo N, Harshfield BJ, McElrath TF, O'Connor GT, et al. Effect of prenatal supplementation with vitamin D on asthma or recurrent wheezing in offspring by age 3 years: the VDAART randomized clinical trial. JAMA (2016) 315(4):362-70. doi:10.1001/jama.2015.18589

77. Vahdaninia M, Mackenzie H, Helps S, Dean T. Prenatal intake of vitamins and allergic outcomes in the offspring: a systematic review and meta-analysis. J Allergy Clin Immunol Pract (2016). doi:10.1016/j.jaip.2016.09.024

78. Busse WW, Lemanske RF Jr, Gern JE. Role of viral respiratory infections in asthma and asthma exacerbations. Lancet (2010) 376(9743):826-34. doi:10.1016/S0140-6736(10)61380-3

79. Morgan WJ, Stern DA, Sherrill DL, Guerra S, Holberg CJ, Guilbert TW, et al. Outcome of asthma and wheezing in the first 6 years of life: follow-up through adolescence. Am J Respir Crit Care Med (2005) 172(10):1253-8. doi:10.1164/ rccm.200504-525OC

80. Prescott SL. Early-life environmental determinants of allergic diseases and the wider pandemic of inflammatory noncommunicable diseases. J Allergy Clin Immunol (2013) 131(1):23-30. doi:10.1016/j.jaci.2012.11.019

81. Anastasiou A, Karras SN, Bais A, Grant WB, Kotsa K, Goulis DG. Ultraviolet radiation and effects on humans: the paradigm of maternal vitamin D production during pregnancy. Eur J Clin Nutr (2016). doi:10.1038/ ejcn.2016.188

82. von Mutius E, Martinez FD. Inconclusive results of randomized trials of prenatal vitamin $\mathrm{D}$ for asthma prevention in offspring: curbing the enthusiasm. JAMA (2016) 315(4):347-8. doi:10.1001/jama.2015.18963

83. Amrein K, Quraishi SA, Litonjua AA, Gibbons FK, Pieber TR, Camargo CA Jr et al. Evidence for a U-shaped relationship between prehospital vitamin D status and mortality: a cohort study. J Clin Endocrinol Metab (2014) 99(4): 1461-9. doi:10.1210/jc.2013-3481

84. Kolokotroni O, Papadopoulou A, Yiallouros PK, Raftopoulos V, Kouta C, Lamnisos D, et al. Association of vitamin D with adiposity measures and other determinants in a cross-sectional study of Cypriot adolescents. Public Health Nutr (2015) 18:112-21. doi:10.1017/S1368980013003480

Conflict of Interest Statement: The authors declare that the research was conducted in the absence of any commercial or financial relationships that could be construed as a potential conflict of interest.

Copyright (c) 2017 Bountouvi, Douros and Papadopoulou. This is an open-access article distributed under the terms of the Creative Commons Attribution License (CC BY). The use, distribution or reproduction in other forums is permitted, provided the original author(s) or licensor are credited and that the original publication in this journal is cited, in accordance with accepted academic practice. No use, distribution or reproduction is permitted which does not comply with these terms. 